\title{
Pendidikan Nasional dan Kualitas Manusia Indonesia Dalam Perspektif Sejarah
}

\author{
Yudi Hartono*
}

\begin{abstract}
Abstrak
Pendidikan yang tepat dan bermutu dapat disiapkan oleh manusia dan masyarakat yang memiliki kemampuan dan keunggulan di masa depan. Untuk mengoptimalkan kontribusi pendidikan, maka semua pihak berkontribusi penting, termasuk pengelola pendidikan itu sendiri, pihak swasta, pemerintah, dan masyarakat pada umumnya. Kontribusi pendidikan terhadap kualitas manusia Indonesia sejak kemerdekaan hingga reformasi menarik untuk dikaji. Orde lama merupakan satu fase yang berusaha membangun masyarakat sipil yang kuat. Orde lama menghapuskan sistem pendidikan elitism pada masa kolonial dan memberlakukan politik persatuan nasional. Pendidikan menjadi wahana penmbangunan karakter bangsa. Orde Baru mengedepankan moto "membangun manusia Indonesia seutuhnya dan masyarakat Indonesia" dan berbagai kebijakan turunannya memberi kontribusi bagi kualitas manusia bagi dunia industri khususnya untuk mendukung pembangunan ekonomi, namun terdapat empat masalah pokok dalam pendidikan di Indonesia: pemerataan, mutu, relevansi, dan efisiensi pendidikan. Era reformasi memberikan ruang yang cukup besar bagi perumusan kebijakan-kebijakan pendidikan baru yang bersifat reformatif dan revolusioner. Namun demikian, sistem pendidikan nasional Indonesia terlihat masih bersifat tambal sulam, mulai dari kebijakan kurikulum, manajemen, sistem pembelajaran, tuntutan kualitas guru, tuntutan fasilitas dan dana pendidikan, kurang memiliki prioritas yang ingin dicapai.
\end{abstract}

Kata Kunci: pendidikan, kualitas sumber daya manusia

\section{Pendahuluan}

Sumber daya manusia merupakan aset utama pembangunan bangsa. Ketersediaan sumber daya alam (natural resources) yang melimpah dan sumber daya modal serta teknologi yang semakin canggih, tidak akan berkontribusi yang bernilai tambah, tanpa didukung sumber daya manusia (human resources) yang berkualitas. Sumber daya manusia yang berkualitas akan dapat dicapai melalui pendidikan. Pendidikan berkontribusi signifikan dalam meningkatkan kualitas suatu bangsa, tentunya juga bagi bangsa
Indonesia. Pendidikan yang berkualitas berkorelasi positif dengan sumber daya manusia yang berkualitas.

Kenyataannya, kualitas pendidikan di Indonesia saat ini masih memprihatinkan. Hal ini dibuktikan antara lain berdasarkan data dalam Education For All (EFA) Global Monitoring Report 2011: The Hidden Crisis, Armed Conflict and Education yang dikeluarkan Organisasi Pendidikan, Ilmu Pengetahuan, dan Kebudayaan Perserikatan Bangsa-Bangsa (UNESCO) yang diluncurkan di New York (1/3/2011), indeks pembangunan pendidikan atau education 
development index (EDI) berdasarkan data tahun 2008 adalah 0,934 . Nilai itu menempatkan Indonesia di posisi ke-69 dari 127 negara di dunia. EDI dikatakan tinggi jika mencapai 0,95-1.

Kategori medium berada di atas 0,80, sedangkan kategori rendah di bawah 0,80. Total nilai EDI itu diperoleh dari rangkuman perolehan empat kategori penilaian, yaitu: angka partisipasi pendidikan dasar, angka melek huruf pada usia 15 tahun ke atas, angka partisipasi menurut kesetaraan jender, angka bertahan siswa hingga kelas V Sekolah Dasar (SD).

Penurunan EDI Indonesia yang cukup tinggi tahun ini terjadi terutama pada kategori penilaian angka bertahan siswa hingga kelas V SD. Kategori ini untuk menunjukkan kualitas pendidikan di jenjang pendidikan dasar yang siklusnya dipatok sedikitnya lima tahun. Saat ini Indonesia masih tertinggal dari Brunei Darussalam yang berada di peringkat ke-34. Brunei Darussalam masuk kelompok pencapaian tinggi bersama Jepang, yang mencapai posisi nomor satu Asia.

Adapun Malaysia berada di peringkat ke-65 atau masih dalam kategori kelompok pencapaian medium seperti halnya Indonesia. Meskipun demikian posisi Indonesia saat ini masih jauh lebih baik dari Filipina (85), Kamboja (102), India (107), dan Laos (109). ${ }^{1}$ Kualitas pendidikan akan berkorelasi dengan kualitas sumber daya manusia.

Berdasarkan laporan Laporan Pembangunan Manusia (Human Development Index/HDI) dari 182 negara, 2 November 2011 oleh Badan Program Pembangunan Perserikatan Bangsa Bangsa (United Nation Development Program/UNDP), Indeks Pembangunan Manusia Indonesia berada pada angka 0.617 dan menempatkan pada peringkat 124 dari 187 negara. Sedangkan HDI Asia Timur dan Pasifik sebagai peringkat regional meningkat dari 0.428 di 1980 menjadi 0.671 saat ini, sehingga menempatkan Indonesia di bawah rata-rata regional.

Dalam laporannya tersebut, UNDP menempatkan Norwegia, Australia dan Belanda berada di posisi tertinggi dalam HDI 2011. Sementara Kongo, Nigeria dan Burundi berada pada peringkat terbawah. ${ }^{2}$

Kondisi kualitas sumber daya manusia (SDM) seperti di atas menyebabkan tingkat daya saing bangsa Indonesia dalam tataran dunia tergolong rendah. Suhendar (2012) menyampaikan bahwa dalam The Global Competitiveness Report 2011-2012 (laporan tahunan daya saing global tahun 20112012) yang dibuat oleh World Economic

\footnotetext{
${ }^{1} \mathrm{http} / / /$ disdikpora.palangkaraya.go.id/beri ta-160-kualitas-pendidikan-indonesiaranking-69-tingkat-dunia.html, diunduh 6 Juni 2015.

${ }^{2}$ http://dunia.news.viva.co.id/news/read/2 60961/kualitas-manusia-indonesia-dibawah-rata-rata, diunduh 6 Juni 2015.
} 
Forum (WEF) menempatkan Indonesia pada posisi ke 46 dari 142 negara di dunia. Pada kawasan ASEAN posisi daya saing Indonesia berada posisi keempat di bawah Singapura, Malaysia, dan Thailand.

Hanya dengan pendidikan yang tepat dan bermutu dapat disiapkan manusia dan masyarakat yang memiliki kemampuan dan keunggulan di masa depan. ${ }^{3}$ Untuk mengoptimalkan kontribusi pendidikan tersebut di atas, maka semua pihak (stakeholders) mempunyai kontribusi yang penting termasuk pengelola pendidikan itu sendiri, pihak swasta, pemerintah, dan masyarakat pada umumnya. Tulisan ini akan membahas kontribusi pendidikan terhadap kualitas manusia Indonesia sejak kemerdekaan hingga reformasi.

\section{Masa Orde Lama}

Pada periode ini kegiatan pendidikan di tanah air lebih mengarah pada pemantapan nilai-nilai nasionalisme, identitas bangsa, dan pembangunan pondasi ideologis kehidupan berbangsa dan bernegara. Tujuan utama pendidikan pada periode ini adalah nation and character building dan kendali utama penyelenggaraan pendidikan nasional dipegang oleh tokoh-tokoh nasionalis. Mereka menguasai berbagai posisi penting di

\footnotetext{
${ }^{3}$ Fasli Jalal \& Dedi Supriadi (ed), Reformasi Pendidikan dalam Konteks Otanomi Daerah (Yogyakarta:Adicita Karya Nusa, 2001), hal. 3.
}

institusi pemerintahan dan secara aktif dan sistematis menjadikan pendidikan sebagai bagian integral dari proses sosialisasi ideologi negara dan penataan corak kehidupan berbangsa dan bernegara.

Menteri PP dan K pertama (Ki Hajar Dewantara) mengeluarkan instruksi umum yang memerintahkankepada semua kepala sekolah dan guru untuk:

1. Mengibarkan Sang Merah Putih setiap hari dihalaman sekolah.

2. Melagukan lagu kebangsaan Indonesia Raya.

3. Menghentikan pengibaran bendera jepang dan menghapus nyanyian Kimiyago (lagu kebangsaan jepang).

4. Menghapus pelajaran bahasa jepang, serta upacara yang berasal dari bala tentara jepang.

5. Memberi semangat kebasaan kepada semua murid. ${ }^{4}$

Tujuan pendidikan nasional pada masa tersebut penekanannya adalah pada penanaman semangat patriotisme dan peningkatan kesadaran nasional, sehingga dengan semangat itu kemerdekaan dapat dipertahankan dan diisi. Kementrian pendidikan, pengajaran dan kebudayaan Rapublik Indonesia dalam tahun 1946 mengeluarkan suatu pedoman bagi guruguru yang memuat sifat-sifat kemanusiaan

${ }^{4}$ Mustafa dan Abdullah, Sejarah Pendidikan Islam di Indonesia, (Bandung: Pustaka Setia, 1998), h. 130. 
dan kewarganegaraan sebagai dasar pengajaran dan pendidikan di negara Republik Indonesia yang pada dasarnya berintisarikan Pancasila. Pada bulan Desember 1949 Republik Indonesia mengalami perubahan ketata negaraan dan Undang-Undang Dasar 1945 diganti dengan konstitusi sementara Rapublik Indonesia Serikat (RIS). Pada tanggal 5 April 1950 mengenai dasar-dasar pendidikan dan pengajaran di sekolah.

Dalam Undang-Undang Nomor 4 Tahun 1950 Bab II Pasal 3 disebutkan bahwa tujuan pendidikan nasional Indonesia adalah membentuk manusia yang asusila dengan cakap dan warga negara yang demokratis serta bertanggung jawab tentang kesejahteraan masyarakat dan tanah air. Hal ini berarti bahwa setiap sistem persekolahan pada waktu itu harus dapat menanamkan dan mengembangkan sifat-sifat demokratis pada anak didiknya misalnya: di dalam kampus muncul kebebasan akademis yang luar biasa ditandai dengan fragmentasi politik yang begitu hebat di kalangan mahasiswamahasiswa bebas berorganisasi sesuai dengan pilihannya. ${ }^{5}$

Sistem persekolahan pada masa Orde Lama hanya mengenal 3 tingkat:

1. Pendidikan rendah, yang terdiri dari taman kanak-kanak (1 tahun) dan sekolah dasar (6 tahun)

${ }^{5}$ Ari H Gunawan, Kebijakan-kebijakan pendidikan, (Jakarta, Renika cipta, 1995), h. 36
2. Pendidikan menengah yang terdiri dari sekolah lanjutan tingkat pertama (SLTP) dan sekolah lanjutan tingkat atas (SLTA) dengan masa belajar untuk masingmasing terdiri atas sekolah umum dan sekolah kejuruan.

3. Pendidikan tinggi selama kurun waktu 1945-1950 berkembang pesat dan terbuka lebar bagi setiap warga negara yang memenuhi syarat, tetapi karena masa perjuangan maka perkuliahan kerap kali disela dengan perjuangan ke garis depan. Pendidikan tinggi yang ada berbentuk universitas atau perguruan tinggi dan akademi.

Para pengajar, pelajar melaksanakan tugasnya dengan sebaik-baiknya walaupun serba terbatas. Dengan segala keterbatasan itu memupuk pemimpin-pemimpin nasional yang dapat mengatasi masa panca roba seperti rongrongan terhadap NKRI.

Kebijakan yang diambil dalam bidang pendidikan tinggi yaitu mendirikan universitas di setiap provinsi. Kebijakan ini bertujuan untuk lebih memberikan kesempatan memperoleh pendidikan tinggi. Pada waktu itu pendidikan tinggi yang bermutu terdapat di pulau Jawa seperti UI, IPB, ITB, Gajah Mada, dan UNAIR, sedangkan di provinsi-provinsi karena kurangnya persiapan dosen dan keterbatasan sarana dan prasarana mengakibatkan kemerosotan mutu pendidikan tinggi mulai terjadi.

Orde lama Presiden Soekarno mencanangkan program pendidikan 
pemberantasan buta huruf, karena selama dijajah Belanda, rakyat tidak bisa menikmati pendidikan sehingga mayoritas buta huruf . 6 Pada masa orde lama ini dapat dibagi menjadi tiga fase yaitu:

1. Periode 1945-1950 (awal kemerdekaan) Usaha untuk memperbaiki tingkat dan mutu pendidikan di Indonesia, maka kaitannya adalah berhubungan dengan:

a) Peningkatan fasilitas fisik (sarana dan prasarana pendidikan)

Pemerintah mendirikan gedunggedung sekolah baru, menyewa rumah rakyat dan mengadakan sistem penggunaan gedung sekolah dua sampai tiga kali sehari yaitu pagi, siang dan malam hari.

b) Peningkatan dan penambahan fasilitas personal sekolah (guru dan tenaga tata usaha)

c) Kurikulum

Setelah UU Pendidikan dan Pengajaran Nomor 4 Tahun 1950 dikeluarkan, maka:

1) Kurikulum pendidikan rendah ditujukan untuk menyiapkan anak agar memiliki dasar-dasar pengetahuan, kecakapan dan ketangkasan baik lahir maupun batin serta mengembangkan bakat dan kesukaannya.

2) Kurikulum pendidikan menengah ditujukan untuk menyiapkan

${ }^{6}$ Anam, S, Sekolah Dasar, Pergulatan Mengejar Ketertinggalan, (Solo: Wijatri), h.113-148 pelajar ke pendidikan tinggi, serta mendidik tenaga-tenaga ahli dalam berbagai lapangan khusus, sesuai dengan bakat masingmasing dan kebutuhan masyarakat.

3) Kurikulum pendidikan tinggi ditujukan untuk menyiapkan mahasiswa agar dapat menjadi pimpinan dalam masyarakat dan dapat memelihara kemajuan ilmu dan kemajuan hidup kemasyarakatan.

Pada tahun ini kedaulatan Indonesia semakin matang dan sempurna, maka rancangan pendidikan agama pada waktu tersebut semakin disempurnakan dengan dibentuknya panitia yang diketuai oleh Prof. Mahmud Yunus dari Departemen Agama dan Mr. Hadi dari departemen P \& K. Hasil dari panitia tersebut adalah SKB yang dikeluarkan pada bulan januari 1951, yang isinya adalah: ${ }^{7}$

1) Pendidikan agama diberikan mulai kelas IV sekolah rakyat (sekolah dasar)

2) Di daerah-daerah yang agamanya kuat (seperti sumtera, Kalimantan dan lain-lain) maka pendidikan agama diberikan mulai kelas I SR dengan catatan bahwa mutu

7Zuhairini dkk, 1986, Sejarah Pendidikan Islam, Proyek Pembinaan Prasarana dan Sarana Perguruan Tinggi Agama, Jakarta, hal. 153. 
pengetahuan umumnya tidak boleh berkurang dibandingkan dengan sekolah lain yang pendidikan agamanya diberikan mulai kelas IV.

3) Di sekolah lanjutan pertama dan atas (umum dan kejuruan) diberikan pendidikan agama sebanyak 2 jam seminggu.

4) Pendidikan agama diberikan pada murid-murid sedikitnya 10 orang dalam satu kelas dan mendapat izin dari orang tua/walinya.

5) Penggngkatan guru agama, biaya pendidikan agama dan materi pendidikan agama di tanggung oleh departemen agama .

\section{Pembiayaan}

Besarnya pembiayaan pendidikan yang dikeluarkan pemerintah pada kurun waktu ini sulit diperoleh angkaangkanya secara pasti, karena sebagaimana kita ketahui bahwa waktu itu kita berada dalam perjuangan fisik untuk mempertahankan kemerdekaan. ${ }^{8}$

Selama perjuangan fisik untuk mempertahankan kemerdekaan Indonesia seluruh lapisan masyarakat telah terlibat, khususnya para pelajar dan mahasiswa yang telah mengalami latihan kemiliteran pada zaman Jepang. Kurikulum pertama pada masa kemerdekaan namanya "Rencana

8Soenarto, N., Biaya Pendidikan di Indonesia : Perbandingan pada Zaman Kolonial Belanda dan NKRI, http://www.kompas.com,
Pelajaran 1947", ketika itu penyebutanya lebih populer menggunakan leer plan (rencana pelajaran).

Rencana pelajaran 1947 bersifat politis, yang tidak mau lagi melihat dunia pendidikan masih menerapkan kurikulum Belanda. Asas pendidikan ditetapkan Pancasila. Susunan rencana pelajaran 1947 sangat sederhana, hanya memuat dua hal pokok, yaitu daftar mata pelajaran dan jam pengajarannya, serta garis-garis besar pengajarannya. ${ }^{9}$

$\begin{array}{ccc}\text { Rencana } & \text { pelajaran lebih } \\ \text { mengutamakan } & \text { pendidikan watak, }\end{array}$
kesadaran bernegara dan bermasyarakat daripada pendidikan pikiran. Materi pelajaran dihubungkan dengan kejadian sehari-hari. Mata pelajaran untuk tingkat sekolah rakyat ada 16, khusus di Jawa, Sunda, dan Madura diberikan bahasa daerah.

Daftar pelajarannya adalah bahasa Indonesia, bahasa daerah, berhitung, ilmu alam, ilmu hayat, ilmu bumi, sejarah, menggambar, menulis, seni suara, pekerjaan tangan, pekerjaan keputrian, gerak badan, kebersihan dan kesehatan, didikan budi pekerja dan pendidikan agama. Garis-garis besar pengajaran pada saat itu menekankan pada cara guru mengajar dan cara murid mempelajari.

9[8] Sanjaya, W. Kajian Kurikulum dan Pembelajaran, Bandung : Sekolah Pasca Sarjana UPI, 2007 
2. Periode 1950-1959 (demokrasi liberal)

a. Sistem persekolahan

$$
\text { Sejak Agustus } 1950
$$

penyelenggaraan pendidikan dan pengajaran menggunakan UndangUndang pokok pendidikan dan pengajaran Nomor 4 Tahun 1950 Republik Indonesia. Susunan sekolah tersebut adalah sekolah rakyat 6 tahun, sekolah lanjutan tingkat pertama 3 tahun, dan sekolah lanjutan tingkat atas 3 tahun. Pada tahun 1954 didirikan lembaga pendidikan guru bertingkat universitas yang pertama yaitu Pendidikan Tinggi Pendidikan Guru (PTPG) di Bandung.

b. Kesempatan belajar

Undang-Undang pendidikan tahun 1950 dan 1959 Pasal 17 menyatakan: Tiap-tiap warga negara Republik Indonesia mempunyai hak yang sama diterima menjadi murid suatu sekolah, jika memenuhi syarat yang ditetapkan unit pendidikan dan pengajaran pada sekolah itu.

Di samping itu, pasal 21 ayat 1 menyatakan pula bahwa: Pemerintah dan bangsa Indonesia menerima koedukasi pendidikan untuk laki-laki dan perempuan bersama-sama.

Dari Undang-Undang tersebut di atas dapatlah diketahui bahwa:

1) Pemerintah memberikan kesempatan belajar bagi setiap golongan masyarakat, seperti anak petani, pedagang, pegawai negeri, pengusaha, anggota ABRI untuk mendapatkan pendidikan mulai dari TK sampai dengan perguruan tinggi.

2) Pemerintah memberikan kesempatan belajar bagi setiap golongan masyarakat untuk mencapai tingkat yang tertinggi, asalkan memenuhi syarat.

3) Pemerintah memberikan kesempatan belajar bagi setiap golongan masyarakat tanpa membedakan apakah anak lakilaki atau perempuan.

Pada tahun 1952 kurikulum di Indonesia mengalami penyempurnaan. Pada tahun 1952 ini diberi nama “Rencana Pelajaran Terurai 1952". Kurikulum ini mengarah pada suatu sistem pendidikan nasional yang paling menonjol dan sekaligus ciri dari kurikulum 1952 ini bahwa setiap rencana pelajaran harus memperhatikan isi pelajaran yang dihubungkan dengan kehidupan sehari-hari.

Pada masa itu juga dibentuk kelas masyarakat, yaitu sekolah khusus bagi lulusan SR 6 tahun yang tidak melanjutkan ke SMP, kelas masyarakat mengajarkan keterampilan seperti pertanian, pertukangan dan perikanan. Tujuannya agar anak tak mampu sekolah ke jenjang SMP bisa langsung bekerja.

3. Periode 1959-1966 (demokrasi terpimpin)

Tujuan pendidikan nasional yang dirumuskan dalam keputusan presiden nomor 145 Tahun 1965 adalah sebagai 
berikut: Tujuan pendidikan nasional baik yang diselenggarakan oleh pihak pemerintah maupun oleh pihak swasta, dari pendidikan pra sekolah sampai pendidikan tinggi supaya melahirkan warga negara sosialis Indonesia yang asusila, yang bertanggung jawab atas terselenggaranya masyarakat sosialis Indonesia adil dan makmur spiritual maupun material dan yang berjiwa Pancasila.

Kebijakan pendidikan pada waktu itu yaitu, "Sapta Usaha Tama Dan Panca Wardhana" tertuang dalam instruksi Menteri PP\&K Nomor 1 Tahun 1959. Sapta Usaha Tama berisi:

Penertiban aparatur dan usaha-usaha kementrian PP\&K:

a. Menggiatkan kesenian dan olahraga.

b. Mengharuskan "usaha halaman".

c. Mengharuskan penabungan.

d. Mewajibkan usaha-usaha koperasi.

e. Mengadakan "kelas masyarakat".

f. Membentuk "regu kerja" di kalangan SLA dan Universitas.

Sementara Panca Wardhana berisikan segi-segi sebagai berikut :

a. Perkembangan cinta bangsa dan tanah air, moral nasional, internal dan keagamaan (moral).

b. Perkembangan intelegensi (kecerdasan).

c. Perkembangan emosional-artistik atau rasa keharuana dan keindahan lahir batin. d. Perkembangan keprigelan (kerajinan) tangan.

e. Perkembangan jasmani.

Konsep pembelajaran pada tahun 1964 mewajibkan sekolah membimbing anak agar mampu memikirkan sendiri pemecahan persoalan (problem solving). Rencana pendidikan 1964 melahirkan kurikulum 1964 yang menitikberatkan pada pengembangan daya cipta, rasa, karya dan moral yang kemudian dikenal dengan istilah panca wardhana.

Pada saat itu pendidikan dasar lebih menekankan pada pengetahuan dan kegiatan fungsional praktis, yang disesuaikan dengan perkembangan anak. Cara belajar dijalankan dengan metode yang disebut gotong royong terpimpin. Selain itu pemerintah menerapkan hari Sabtu sebagai hari krida, maksudnya, pada hari Sabtu siswa diberi kebebasan berlatih kegiatan di bidang kebudayaan, kesenian, olahraga, dan permainan sesuai minat siswa. Kurikulum 1964 adalah alat untuk membentuk manusia Pancasilais yang sosialis Indonesia, dengan sifat-sifat seperti pada ketetapan MPKS No. 11 Tahun 1960.

Penyelenggaraan pendidikan dengan kurikulum 1964 mengubah penilaian di rapor bagi kelas I dan II yang asalnya berupa skor 10-100 menjadi huruf A, B, C, dan D. Sedangkan, bagi kelas III hingga VI tetap menggunakan skor 10-100. Dengan demikian, pada masa orde 
lama, usaha pendidikan pertama ditujukan ke penambahan jumlah dan jenis sekolah sesuai dengan tuntutan rakyat. Pada masa ini untuk kali pertama sejak kemerdekaan ditetapkan Undang-undang No. 12 Tahun 1950 tentang Dasar-Dasar Pendidikan dan Pengajaran Di Sekolah disingkat UUPP.

Usaha pembaharuan pendidikan juga dilakukan karena isi dan caracara pengajaran yang berlaku dianggap tidak sesuai dengan UUPP. Serangan ditujukan terhadap pengajaran klasikal bersifat intelektualistis atau hanya mengutamakan pembentukan akal. Untuk itu diperlukan pengajaran yang dapat membentuk kepribadian, dapat mengembangkan kepercayaan diri, menimbulkan keberanian, inisiatif, dan semangat kerja. ${ }^{10}$

Djumhur dan Danasuparta, mengatakan bahwa pembaharuan pendidikan masa orde lama meliputi:

a. Pembatasan bahan pelajaran sampai ke pengetahuan yang siap pakai secara efektif.

b. Usaha ke arah individualisasi dan keaktifan peserta didik.

c. Melepaskan hubungan kelas yang kaku.

${ }^{10}$ I. Djumhur \& Danasuparta, op.cit., h. 217. d. Menugaskan peserta didik untuk lebih banyak bekerja secara kelompok.

e. Menghubungkan sekolah dengan masyarakat.

f. Mencurahkan perhatian lebih banyak kepada perkembangan perasaan nasionalis, etis, estetis, dan pembentukan watak. ${ }^{11}$

Kebijakan pendidikan pada masa orde lama sesuai dengan tujuan negara, yaitu pendidikan nasionalisme Indonesia oleh pemerintahan Ir. Soekarno (1961-1966). Menteri pendidikan pertama Ki Hajar Dewantara beberapa bulan sesudah proklamasi mengeluarkan instruksi umum, yang isinya menyerukan kepada para pengurus upaya membuang sistem pendidikan kolonial dan mengutamakan patriotisme.

Sosialisme Indonesia yang dijalankan oleh pemerintah, di tingkatan ke kebijakan, sampai penerapannya dilingkungan pendidikan formal SMP, SMA, dan perguruan tinggi, merupakan salah satu cara menjelaskan tujuan pendidikan dengan tujuan Negara. Pemerintah membuat suatu kurikulum yang sesuai dengan tujuan tersebut, dan lahirlah mata pelajaran Ilmu Kewargaan Negara atau Civics, yang diajarkan di tingkat SMP dan SMA.

\footnotetext{
11Ibid., h. 222.
} 
Indonesia di era Orde Lama merupakan Negara yang sarat dengan cita-cita sosialisme. Cita-cita sosialisme ini termasuk juga dalam bidang pendidikan. Statuta Universitas Gadjah Mada (UGM) tahun 1951 sangat tegas menyatakan bahwa tujuan UGM adalah menyokong sosialisme pendidikan. Namun, pada tahun 1992, di bawah kekuasaan Orde Baru, statute ini diganti dengan banyak perubahan pada isinya.

Satu perubahannya adalah menghilangkan pasal mengenai tujuan menyokong sosialisme pendidikan Indonesia. Kebijakan pendidikan saat itu dilakukan secara sentralistik, sebagaimana dijelaskan oleh Tilaar (2000: 2) bahwa kebijakan pendidikan di masa ini diarahkan kepada proses indoktrinasi dan menolak segala unsur budaya yang datangnya dari luar.

Semangat diskriminatif di dalam sekolah formal mulai dikikis. Anak-anak dari kalangan buruh dan tani mulai bisa menikmati dan mengenyam bangku pendidikan. Secara yuridis, pemikiran tentang pendidikan nasional dapat dilacak dalam Undang-undang Nomor 4 Tahun 1950 tentang dasar-dasar pendidikan dan pengajaran di sekolah (Lembaran Negara Tahun 1950 Nomor 550) yang pelaksanaannya ditegaskan UU No.12 Tahun 1954, tentang berlakunya UU No. 4 Tahun 1950 tentang dasar-dasar pendidikan dan pengajaran di sekolah untuk seluruh Indonesia (lembaran Negara Tahun 1954 Nomor 38. Tambahan lembaran Negara Nomor 550).

Tujuan dan dasar pendidikan pada Orde Lama dapat dilihat pada pasal 3 dan 4. Pasal 3: Tujuan pendidikan dan pengajaran adalah membentuk manusia susila yang cakap dan warga Negara yang demokratis serta bertanggungjawab tentang kesejahteraan masyarakatdan tanah air. Pasal 4: pendidikan dan pengajaran berdasarkan atas asas-asas yang termaktub dalam Pancasila, UUD Negara Republik Indonesia dan atas kebudayaan kebangsaan Indonesia.

Pada masa Orde Lama pendidikan banyak diarahkan untuk nation and character building. Pemerintahan secara aktif dan sistematis menjadikan pendidikan sebagai bagian integral dari proses sosialisasi ideologi negara dan penataan corak kehidupan berbangsa dan bernegara. Konsep pendidikan ini akhirnya berakhir pada Tahun 1965.

\section{Masa Orde Baru}

Fokus utama pembangunan nasional pada era Orde Baru adalah bidang ekonomi, maka pelaksanaan kegiatan kependidikan pada era ini 
difungsikan sebagai instrumen pembangunan ekonomi nasional. Strategi, fokus, dan pendekatan pendidikan tersebut dijalankan dengan paradigma sentralisasi.

Kebijakan pendidikan semuanya terpusat. Kurikulum ditetapkan di pusat, tenaga pendidikan ditentukan dari pusat, sarana dan prasarana pendidikan diberikan dari pusat, dana pendidikan ditentukan dari pusat, semuanya diseragamkan dari pusat. Maka yang terjadi adalah masyarakat pasif, tidak tahu dan tidak dapat berlibat di dalam kehidupan pendidikan. Padahal, masyarakat memiliki harapan dan dampak terhadap upaya pendidikan di Indonesia, walaupun mereka mempunyai perbedaan dalam status sosial, peranan dan tanggungjawab.

Hal yang ironis lagi adalah menempatkan pendidikan sebagai kerja non-akademik, pendidikan diselenggarakan dengan otorita kekuasaan administratifbirokratis, belum menempatkan pendidikan sebagai kerja akademik dan penyelenggaraan pendidikan dibawah otorita keilmuan.

Darmaningtyas mengungkapkan bahwa politik penyeragaman pada masa Orde Baru tidak hanya secara fisik seperti pakaian, melainkan juga pola pikir, sikap, dan cara kerja melalui kurikulum. Kebijakan pakaian seragam diberlakukan sejak tahun 1978 dan berlaku umum tanpa perkecualian, sehingga sejak saat itu warna, jenis, dan bentuk pakaian sekolah di seluruh
Indonesia untuk satu jenis sekolah semua sama. Penyeragaman pola pikir, sikap, dan cara kerja dilakukan melalui sentralisasi kurikulum, pembakuan metode mengajar dan alat tes, sampai dengan penentuan kriteria kenaikan ataupun kelulusan peserta didik. ${ }^{12}$

Materi kurikulum pendidikan nasional dari Taman Kanak-kanak hingga Sekolah Menengah Atas, bahkan perguruan tinggi dibuat seragam tanpa melihat karakteristik setiap daerah. Penyeragaman kurikulum juga diikuti dengan penyeragaman metode mengajar dan sistem evaluasi. Metode Cara Belajar Siswa Aktif disingkat CBSA diterapkan di seluruh wilayah Indonesia. Padahal, metode CBSA hanya tepat diterapkan di sekolah yang jumlah gurunya cukup, siswanya responsif, fasilitas pendidikan cukup memadai, dan didukung oleh informasi yang luas. Demikian pula, sistem evaluasi belajar dengan tes objektif diseragamkan di seluruh Indonesia. ${ }^{13}$

Pemerintahan Orde Baru mengedepankan moto "membangun manusia Indonesia seutuhnya dan masyarakat Indonesia". Pada tahun 19691970 diadakan Proyek Penilaian Nasional Pendidikan (PPNP) dan menemukan empat masalah pokok dalam pendidikan di

\footnotetext{
${ }^{12}$ Darmaningtyas, Pendidikan Pada dan Setelah Krisis, Pustaka Pelajar,Yogyakarta, 1999, h. 129130.

${ }^{13}$ Ibid., h. 130-132.
} 
Indonesia: pemerataan, mutu, relevansi, dan efisiensi pendidikan. Dan hasilnya digunakan untuk membentuk Badan Penelitian dan Pengembangan Pendidikan dan Kebudayaan (BP3K). Depdiknas di bawah Menteri Wardiman Djojohadiningrat (kabinet pembangunan VI) mengedepankan wacana pendidikan "link and match"sebagai upaya untuk memperbaiki pendidikan Indonesia pada masa itu (Rianti Nugroho, 2008: 16).

Relevansi pendidikan diperhatikan dengan penyesuaian isi pendidikan dengan kebutuhan pembangunan terhadap sumber daya manusia yang diperlukan. Kebijakan ini secara eksplisit muncul pada pelita I, II, III, I dan V. Setelah perluasan kesempatan belajar, sasaran perbaikan bidang pendidikan selanjutnya adalah pemberantasan buta aksara. Kenyataan bahwa masih banyak penduduk yang buta huruf ditanggapi pemerintahan Soeharto dengan pencanangan penuntasan buta huruf pada 16 Agustus 1978. Tekniknya adalah dengan pembentukan kelompok belajar atau kejar.

Dengan mencanangkan wajib belajar 9 tahun, termasuk juga yang tak kalah populer adalah dibukanya program SD Inpres untuk daerah-daerah terpencil dan terisolir di berbagai belahan daerah di Indonesia. Program wajib belajar dicanangkan pada 2 Mei 1984. Bank Dunia pada tahun-tahun akhir 1970-an dan awal tahun 1980-an memberikan resep untuk meningkatkan efektivitas pendidikan guru dengan merombak kurikulum IKIP yang semula mirip kurikulum Universitas menjadi khas IKIP, dimana kurikulum baru ini terlalu berlebih-lebihan menekankan pembelajaran dan mengurangi secara besarbesaran materi bidang studi. Para pedagogi yang tidak sepaham dengan resep ini dengan sinis mengatakan bahwa di kurikulum IKIP yang baru ini, bagaimana cara memegang kapur pun diajarkan.

Mutu guru lulusan IKIP merosot tajam. Guru menguasai berbagai pendekatan dan metodologi mengajar, tetapi tidak menguasai apa yang harus diajarkan. Kebijakan ke dua dalam peningkatan mutu pendidikan adalah dengan meningkatkan kualitas guru lewat projek peningkatan mutu guru yang dilakukan dengan model pelatihan guru yang sangat terencana mulai dari teori, praktik sampai on the job training di sekolah masing-masing.

Secara umum praktek pendidikan juga mengalami variasi pula yang dibedakan menurut jenis, jalur, dan jenjang pendidikan.

1. Jenis pendidikan

Pada umumnya pendidikan menurut jenisnya dibedakan menjadi tiga macam, yaitu:

a. Pendidikan Formal, menunjuk pada sistem pendidikan persekolahan.

Pendidikan jenis ini atau sistem persekolahan ini adalah jenis 
pendidikan yang sudah terstandarisasi secara legal-formal. Baik dalam jenjang-jenjangnya, lama belajarnya, paket kurikulumnya, persyaratan unsur pengelolaannya, persyaratan usia.

b. Pendidikan nonformal, memiliki karakteristik yang berbeda dengan yang di atas, dapat dikatakan relatif lebih lentur, fleksibel, dan berjangka pendekprogram penyelenggaraannya dibandingkan dengan jenis pendidikan formal.

c. Pendidikan informal, jenis pendidikan yang tidak terorganisir secara terstruktur, lebih merupakan hasil pengalaman belajar individualmandiri. Bentuk nyata dari jenis pendidikan ini adalah pendidikan dalam keluarga. Dalam keluarga tidak dikenal standardisasi program, kurikulum, jenjang dan lain-lain. Contoh lain: pendidikan media massa, acara-acara keagamaan, dan lain-lain.

2. Jalur pendidikan

Menurut jalurnya, pendidikan dibedakan menjadi dua, yaitu jalur sekolah dan jalur luar sekolah. Jalur sekolah merupakan jalur pendidikan yang berjenjang dan berkesinambungan. Jalur ini dilaksanakan oleh sekolah melalui kegiatan belajar mengajar. Jalur sekolah ini terdiri atas sekolah-sekolah yang berjenis pendidikan umum, pendidikan kejuaraan, pendidikan luar biasa, pendidikan kedinasan, pendidikan keagamaan, pendidikan akademik, dan pendidikan profesional.

Sedangkan jalur pendidikan luar sekolah merupakan jalur pendidikan yang diselenggarakan diluar pendidikan sekolah melalui kegiatan belajar mengajar yang tidak harus berjenjang dan berkesinambungan, jalur ini umumnya diselenggarakan oleh keluarga, kelompok belajar, lembaga kursus, dan satuan-satuan yang sejenis.

3. Jenjang pendidikan

Pendidikan ditinjau dari jenjangnya terdiri dari: a) jenjang pra sekolah, b) jenjang pendidikan dasar, c) jenjang pendidikan menengah, dan d) jenjang pendidikan tinggi. Keempat-empatnya merupakan mata rantai yang berkesinambungan. Jenjang pendidikan pra sekolah wujudnya adalah: kelompok bermain (play group) dan Taman Kanakkanak (TK). Jenjang pendidikan dasar (SD), Madrassh Ibtidaiyyah (MI), Sekolah Lanjutan Tingkat Pertama (SLTP), serta Madrasah Tsanawiyyah (MTs). Jenjang pendidikan menengah adalah Sekolah Menengah Umum (SMU), Sekolah Menengah Kejuruan (SMK) dan Madrasah Aliyah (MA), adapun jenjang pendidikan tinggi yaitu contohnya UIN, UNY, UGM, dan lain-lain. ${ }^{14}$

\footnotetext{
${ }^{14}$ Arif Rohman, Politik Ideologi Pendidikan, (Yogyakarta: LaksBang Mediatama, 2009), h. 174.
} 
Pemerintahan Orde Baru mengedepankan moto membangun manusia Indonesia seutuhnya dan masyarakat Indonesia dan berbagai kebijakan turunannya memberi kontribusi bagi kualitas manusia bagi dunia industri untuk mendukung pembangunan ekonomi, namun terdapat empat masalah pokok dalam pendidikan di Indonesia: pemerataan, mutu, relevansi, dan efisiensi pendidikan.

\section{Masa Reformasi}

Pada periode ini semangat desentralisasi, demokratisasi, dan globalisasi yang dibawa oleh gerakan reformasi menjalar ke semua sektor pembangunan, termasuk sektor pendidikan sehingga menjadi tema utama penataan sistem pendidikan nasional. Pasca Reformasi tahun 1998, terjadi perubahan fundamental dalam sistem pendidikan nasional. Perubahan sistem pendidikan tersebut mengikuti perubahan sistem pemerintah yang sentralistik menuju desentralistik atau yang lebih dikenal dengan otonomi pendidikan dan kebijakan otonomi nasional itu mempengaruhi sistem pendidikan.

Sistem pendidikan nasional menyesuaikan dengan model otonomi. Di tingkat manajemen diberlakukan Manajemen Berbasis Sekolah dan di tingkat kurikulum diberlakukan Kurikulum Berbasis Kompetensi disingkat KBK dan Kurikulum Tingkat Satuan Pelajaran disingkat KTSP. KBK menekankan pada eksplorasi kemampuan atau potensi peserta didik secara optimal, membangun apa yang dipelajari dan mengupayakan penerapan dalam kehidupan sehari-hari.

KBK berupaya mengkondisikan setiap peserta didik agar memiliki pengetahuan, keterampilan, sikap dan nilainilai yang diwujudkan dalam kebiasaan berpikir dan bertindak sehingga proses penyampaiannya harus bersifat kontekstual dengan mempertimbangkan faktor kemampuan, lingkungan, sumber daya, norma, integrasi dan aplikasi berbagai kecakapan kinerja.

Menurut Rosiman, KBK berorientasi pada pendekatan konstruktivisme yang terlihat dari ciri-ciri: menekankan pada ketercapaian kompetensi siswa, baik secara individual maupun klasikal, berorientasi pada hasil belajar dan keberagaman, penyampaian dalam pembelajaran menggunakan pendekatan dan metode yang bervariasi, sumber belajar bukan hanya guru, tetapi juga sumber belajar yang lain yang memenuhi unsur edukasi, penilaian menekankan pada proses dan hasil dalam upaya penguasaan atau pencapaian suatu kompetensi. 15

Salah satu implikasi dari KBK guru harus lebih banyak waktu dan tenaga untuk

${ }^{15}$ Rosiman, Kurikukulum Berbasis Kompetensi Sebagai Persiapan Ke Kurikulum Tingkat Satuan Pendidikan (KTSP) dalam http://labschoolunj.sch.id/smpjkt/publikasi.php?action= artikel\&id=605, diakses 9 Maret 2009. 
memperhatikan siswa secara individual. Tarsudi mengemukakan bahwa dengan jumlah siswa setiap kelas tidak kurang dari 40 orang, ditambah lagi jumlah kelas pararel yang harus diampunya, bukan hanya melelahkan guru, tetapi juga akan berdampak kepada intensitas dan keajegan dalam mengelola kelas menjadi tidak dapat dipertahankannya lagi untuk memperoleh hasil penilaian seobjektif dan seadil mungkin. ${ }^{16}$

Bebarapa pakar dan praktisi pendidikan mencermati kebijakan otonomi pendidikan sering dipahami sebagai indikasi kearah liberalisasi atau lebih parah lagi dikatakan sebagai indikasi ke arah komersialisasi pendidikan. Hal ini, menurut Suyanto, semakin dikuatkan dengan terbentuknya Badan Hukum Pendidikan (BHP) yang oleh beberapa pengamat dianggap sebagai pengejawantahan dari sistem yang mengarah pada liberalisasi pendidikan.

Apakah sistem pendidikan yang ada saat ini telah efektif untuk mendidik bangsa Indonesia menjadi bangsa yang modern, memiliki kemampuan daya saing yang tinggi di tengah-tengah bangsa lain? Menurut Suyanto, berbicara kemampuan, kita sebagai bangsa nampaknya belum sepenuhnya siap benar menghadapi tantangan persaingan. Sementara, disatu sisi, bidang pendidikan kita menjadi

16Tarsudi, Memandang KBK Komprehensif, dalam Suara Merdeka Edisi Senin, 04 Juli 2005. tumpuan harapan bagi peningkatan kualitas Sumber Daya Manusia Indonesia. Tetapi disisi lain, sistem pendidikan kita masih melahirkan mismatch terhadap tuntutan dunia kerja, baik secara nasional maupun regional. ${ }^{17}$

Selain perubahan dari sentralisasi ke desentralisasi yang membawa banyak perubahan juga bagaimana untuk meningkatkan mutu sumber daya manusia dalam menghadapi persaingan bebas abad ke-21. Kebutuhan ini ditampung dalam Undang-Undang No. 14 Tahun 2005 tentang Guru dan Dosen, serta pentingnya tenaga guru dan dosen sebagai ujung tombak dari reformasi pendidikan nasional.

Undang-undang nomor 14 tahun 2005 tentang guru dan dosen Pasal 2 ayat (1) Guru sebagai tenaga profesional mengandung arti bahwa pekerjaan guru hanya dapat dilakukan oleh seseorang yang memiliki kualifikasi akademik, kompetensi, dan sertifikat pendidik sesuai dengan persyaratan untuk setiap jenis dan jenjang pendidikan tertentu. Pasal (4) Yang dimaksud dengan guru sebagai agen pembelajaran (learning agent) adalah peran guru antara lain sebagai fasilitator, motivator, pemacu, perekayasa pembelajaran, dan pemberi inspirasi belajar bagi peserta didik.

\footnotetext{
${ }^{17}$ Suyanto, 2006, Dinamika Pendidikan Nasional Dalam Percaturan Dunia Global(Jakarta: PSAP Muhammadiyah, 2006), h.21.
} 
Sistem Pendidikan Nasional Era Reformasi yang diatur dalam UndangUndang No. 20 Tahun 2003 diuraikan dalam indikator-indikator akan keberhasilan atau kegagalannya, maka lahirlah Peraturan Pemerintah No. 19 Tahun 2005 tentang Standar Nasional Pendidikan yang kemudian dijelaskan dalam Permendiknas RI.

Anggaran pendidikan ditetapkan sesuai dengan UUD 1945 yaitu 20\% dari APBN dan APBD, sehingga banyak terjadi reformasi di dunia pendidikan, terutama dalam dalam pemberian dana Bantuan Operasional Sekolah (BOS), Wajib Belajar 9 tahun, dan peningkatan standar penghasilan Guru dengan adanya sertifikasi guru, serta pemberian bantuan pendidikan (Beasiswa) untuk peningkatan kompetensi guru, dan sebaginya.

Pasal 39 Ayat (2) Undang-Undang Nomor 20 tahun 2003 tentang sistem pendidikan nasional bahwa pendidik merupakan tenaga profesional. Kedudukan guru dan dosen sebagai tenaga profesional mempunyai visi terwujudnya penyelenggaraan pembelajaran sesuai dengan prinsip-prinsip profesionalitas untuk memenuhi hak yang sama bagi setiap warga negara dalam memperoleh pendidikan yang bermutu.

Menurut beberapa pakar dan praktisi pendidikan, reformasi pendidikan Indonesia kurang menggambarkan rumusan-rumusan permasalahan dan prioritas pendidikan yang akan dicapai. Akibatnya, muncul berbagai masalah dalam dunia pendidikan kita yang belum teratasi. Permasalahan tersebut antara lain kinerja yang tidak pas dengan tujuan umum pendidikan nasional, produk pendidikan yang belum siap pakai, atau tidak sesuai dengan ketersediaan lapangan kerja, rangking pendidikan kita di mata dunia yang setara dengan negara-negara miskin atau baru merdeka.

$$
\text { Menyongsong berbagai }
$$

kecenderungan yang aktual tidak ada alternatif lain selain perlu penataan kembali terhadap dunia pendidikan mulai dari filsafat dan tujuan pendidikan, manajemen pendidikan, kurikulum, metode pembelajaran, dan substansi pengajaran secara nasional, regional dan lokal.Sistem pendidikan nasional Indonesia terlihat masih bersifat tambal sulam, mulai dari kebijakan kurikulum, manajemen, sistem pembelajaran, tuntutan kualitas guru, tuntutan fasilitas dan dana pendidikan, kurang memliki prioritas yang ingin dicapai. Sementara secara umum, pendidikan seringkali dipandang sebagai investasi modal jangka panjang yang harus mampu membekali peserta didik untuk menghadapi kehidupan masa depannya. Pendidikan harus mampu mencerahkan peserta didik dari ketidaktahuan menjadi tahu dan memberdayakan, artinya pendidikan mampu membuat mereka berhasil dalam kehidupan. Secara ideal, 
dunia pendidikan harus mampu berjalan beriringan dengan dunia luar. Kendala utama yang dihadapi adalah komitmen pemerintah yang tidak terfokus pada prioritas dalam hal dana pendidikan, baik pada masa lalu dan masa kini. Akibatnya, idealisme tersebut masih jauh dari impian dan jauh dari kenyataan.

Dengan demikian, dapat dikatakan bahwa sebenarnya kesadaran pemerintah Indonesia atas masalah pendidikan masih sangat rendah dibandingkan perhatian pada sektor lain. Alokasi anggaran pendidikan seharusnya menjadi urutan utama untuk pengembangan sumber daya manusia Indonesia, tetapi kenyataan anggaran pendidikan selalu terkalahkan unutuk kepentingan pembangunan sektor lain terutama untuk sektor ekonomi.

Berbagai problem pendidikan yang muncul tersebut di atas bersumber pada kelemahan pendidikan nasional yang sangat mendasar, sehingga tidak mungkin disempurnakan hanya lewat pembaharuan yang bersifat tambal sulam (Erratic). Pembaharuan pendidikan nasional yang mendasar dan menyeluruh harus dimulai dari mencari penjelasan baru atas paradigma peran pendidikan dalam pembangunan (Zamroni, 2000:5-6). ${ }^{18}$

Paradigma tersebut harus berimplikasi pada perubahan perspektif dalam pembangunan pendidikan, mulai dari

18Zamroni, Paradigma Pendidikan Masa Depan, (Yogyakarta: Adipura, 2000), h. 5-6. perspektif yang menganggap pendidikan sebagai sektor pelayanan umum ke perspektif pendidikan sebagai suatu investasi produk yang mampu mendorong pertumbuhan masyarakat di berbagai bidang kehidupan. Pendidikan bukan bidang yang terlepas dari kehidupan lainnya. Antara pendidikan dengan kehidupan hampir-hampir tidak dapat dibedakan sama sekali (life is education, and education is life). 19

Pendidikan dan kehidupan telah menyatu dalam sebuah kerangka filosofis, bahwa proses pendidikan tidak lain adalah proses memanusiakan manusia. Dengan dasar ini, maka pendidikan dipandang sebagai katalisator dan tenaga penggerak yang dapat menyebabkan faktor-faktor lainnya berkembang. Hal ini memberikan aksentuasi betapa pembangunan pendidikan sebagai upaya pengembangan sumberdaya manusia menjadi semakin penting dalam pembangunan suatu bangsa.

\section{Penutup}

Dari paparan tentang pendidikan dan kualitas manusia Indonesia sejak kemerdekaan hingga era reformasi maka penulis dapat mengampil simpulan sebagai berikut:

1. Orde lama merupakan satu fase yang berusaha membangun masyarakat sipil

\footnotetext{
${ }^{19}$ Suyanto, 2006, Dinamika Pendidikan Nasional Dalam Percaturan Dunia Global(Jakarta: PSAP Muhammadiyah, 2006), h.ix.
} 
yang kuat, yang berdiri di atas demokrasi, kesamaan hak dan kewajiban antara sesame warga Negara termasuk dalam bidang pendidikan. Inilah amanat UUD 1945 yang menyebutkan salah satu cita-cita pembangunan nasional adalah mencerdaskan bangsa. Era orde lama menghapuskan sistem pendidikan elitisme pada masa kolonial dan memberlakukan politik persatuan nasional. Pendidikan menjadi wahana pembangunan karakter bangsa.

2. Orde Baru mengedepankan moto membangun manusia Indonesia seutuhnya dan masyarakat Indonesia dan berbagai kebijakan turunannya memberi kontribusi bagi kualitas manusia bagi dunia industri khususnya untuk mendukung pembangunan ekonomi, namun terdapat empat masalah pokok dalam pendidikan di Indonesia: pemerataan, mutu, relevansi, dan efisiensi pendidikan.

Era reformasi memberikan ruang yang cukup besar bagi perumusan kebijakan-kebijakan pendidikan baru yang bersifat reformatif dan revolusioner. Bentuk kurikulum menjadi berbasis kompetensi. Begitu pula bentuk pelaksanaan pendidikan berubah dari sentralistik menjadi desentralistik. Anggaran pendidikan ditetapkan sesuai dengan UUD 1945 yaitu 20\% dari APBN dan APBD, sehingga banyak terjadi reformasi di dunia pendidikan dan memberi peluang peningkatan kualitas sumber daya manusia.

Namun, sistem pendidikan nasional Indonesia terlihat masih bersifat tambal sulam, mulai dari kebijakan kurikulum, manajemen, sistem pembelajaran, tuntutan kualitas guru, tuntutan fasilitas dan dana pendidikan, kurang memiliki prioritas yang ingin dicapai.

\section{Daftar Pustaka}

Ari H Gunawan. 1995. Kebijakan-kebijakan Pendidikan. Jakarta: Renika cipta.

Fasli Jalal \& Dedi Supriadi (ed). 2001. Reformasi Pendidikan dalam Konteks Otanomi Daerah Yogyakarta: Adicita Karya Nusa.

I. Djumhur \& H. Danasuparta. 1975. Sejarah Pendidikan. Bandung: CV. Ilmu.

Muh. Said \& Juminar Affan, Mendidik dari Zaman ke Zaman, Jemmars, Bandung, 1987.

Sanjaya, W. 2007. Kajian Kurikulum dan Pembelajaran. Bandung: Sekolah Pasca Sarjana UPI.

Suyanto \& Djihad Hisyam. 2000. Refleksi dan Reformasi Pendidikan di Indonesia Memasuki Milenium III, Adicita Karya Nusa, Yogyakarta.

Suyanto. 2006. Dinamika Pendidikan Nasional Dalam Percaturan Dunia Global, PSAP Muhammadiyah, Jakarta.

Soedjiarto. 1999. Memahami Arahan Kebijakan GBHN 1999-2004 tentang Pendidikan Sebagai Upaya Mencerdaskan Kehidupan Bangsa dan Membangun Peradaban Negara bangsa Indonesia, makalah, PrimagamaIPSI-PGRI, Yogyakarta.

Tilaar, H.A.R.. 1998. Beberapa Agenda Reformasi Pendidikan Nasional 
Dalam Perspektif Abad 21, Tera Indonesia, Magelang.

Zamroni. 2000. Paradigma Pendidikan Masa

Depan, Adipura, Yogyakarta.

\section{Internet:}

http://disdikpora.palangkaraya.go.id/berita -160-kualitas-pendidikan-indonesiaranking-69-tingkat-dunia.html

http://dunia.news.viva.co.id/news/read/26 0961/kualitas-manusia-indonesiadi-bawah-rata-rata.

http://www.kompas.com 